\title{
Multicultural Approach in Learning as the Attempt of Reinforcing Indonesian Diversity in Elementary School
}

\author{
Suswandari ${ }^{1}$ \\ ${ }^{1}$ Master of Social Science Education Study Program Prof. DR. HAMKA Muhammadiyah University \\ of Jakarta \\ Email: bsuswandari@yahoo.com
}

\begin{abstract}
These days, the dynamics of social interaction in Indonesia is affected by various issues that are threatening the diversity of the Unitary Republic of Indonesia (NKRI). This study aims to describe the multicultural approach in learning in elementary school as an effort to strengthen the student's values of multiculturalism from an early age. The descriptive qualitative method is used to analyze various problems related to the implementation of multicultural approach in learning. The research was conducted in five public elementary schools in PasarRebo Sub-district, East Jakarta. The results of the research explains that the multicultural approach should be a soft skill for the teachers and all components of the primary school management as an effort in fostering tolerance, living in peace, mutual protection, mutual freedom from threats, and to achieve the peaceful and harmonious Indonesia.
\end{abstract}

\section{INTRODUCTION}

A variety of social symptoms color the representation of social interaction in Indonesia in the last decade. Political event of DKI Jakarta Governor Election can be raised as an example of how fragile the national consensus is "as aunity nation" where a variety of differences is melted and proclaimed into Republic of Indonesia Unity State (thereafter called NKRI) on August 17, 1945. Social tension is triggered by development, justice and welfare, ethnic and belief, legal power, women and children violence, disability issues, and etc, as the little part of Indonesian social phenomenon description. Information technology is the global mediator accelerating the construction of public opinion for many power interests and sometimes ignoring humanity interest and values. Moreover, democratic climate has led to a demand for infinite freedom, digital era triggers uncontrolled opinion, demanding for right but avoiding obligation [13] and often ending up in social conflict.

Global era with all of its positive and negative effect will be a serious threat to the sturdiness ofthis multicultural-based NKRI. Multiculturalism is often defined as the attempt of institutionalizing cultural diversity belonging to ethnic groups in a nation-state through language, legal system, gender, social class difference, and government policy in relation to health, education, housing, economy, and welfare [21]. Multicultural attitude is the one recognizing difference and diversity in the frame of commonality and equality. Multicultural attitude characterized, among others, bycommonality and equality that can be built through developing awareness 
of self identity and nationality ideals as the national consensus through education practice with multicultural approach.

Education is up to nowbelieved as a strategic means of establishing and reinforcing national self-identity, of solidifying the nation's ideals in any areas including Indonesia. Education within which the learning process is contained presentsa variety of subjects consistent with vision and mission to be achieved from local, national and international level from basic education to university levels. Social Science is one of subjects in elementary school contributing directly to the establishment of nationality value and character based on religion. The feelings of love to homeland, tolerance, caring about the fellows, having high social sensitivity overthe feeling of individualism developing currently are a part of values contained in all teaching materials of Social Science in Elementary School.

This writing tried to contribute thought related to multicultural approach in Social Science learning in the attempt of Indonesian diversity in elementary school. The explanation starts with explaining multicultural education concept, Social Science Learning and its implementation in learning process.

\section{Multicultural Definition and Multicultural Education}

Indonesian multicultural reality has inspired many stakeholders to present many studies about multiculturalism and multicultural education. Republic of Indonesia's President in some visits abroad or welcoming the state guests often explains the multiculturalism Indonesian has. It can be seen from the guest welcoming ceremony featuring Indonesian diversity attributes. Multiculturalism is a belief and behavior system recognizing and respecting all diverse groups in an organization or society [2]. Multiculturalism is an institutionalization of cultural diversity belonging to ethnic groups in a nation state through language, legal field or system, government policy in health, and housing, education and etc. Multiculturalism is a perception recognizing difference and diversity in a frame of commonality and equality. Democracy is one of spirits guaranteeing multiculturalism [15]. Multicultural attitude is characterized by individual behavior representing the attitude highly appreciating difference, wisdom to receive difference infinitely as a unity, having a strong nationality insight, having undoubted cross-cultural insight and always wishing to live adjacently in peace and harmony.

Indonesian diversity can be represented in the presence of social differentiation in the form of religious, cultural, ethnic, social, political orientation, group affiliation and other differences [16]. The data existing shows that there are at least 20 largest ethnics in Indonesia with Javanese as the largestone with 83.9 millions (41.7\%) out of 201 millions total Indonesian populations, followed with Sundanese with 31 millions (15.4\%), Malayan, Madura, Batak, Minangkabau, Betawi, Bugis and Banten ethnics with 4-7 millions (2\%-4.5\%). Chinese community is the smallest ethnic with $1,738,936$ people $(0.86 \%)$ [17]. In multiculturalism, society has culture prevailing generally within the society, the motif of which is like mosaic (Parsudi, Suparlan, 1989), involving all cultures of smaller communities establishing a larger community. The differenceexisting so far should be recognized as glue, a means of unifying the existing differences into one same objective.

Multiculturalism recognizes and upholds the difference within society, both descriptive and normative differences, the existing difference is not only known but 
also recognized in egalitarian and democratic life. Without multiculturalism consciousness, nationalism built so far in Indonesia will be broken by conflict and separatist movement [16]. Indonesian multiculturalism solidified in bhineka tunggalika (unity in diversity) should remain to stand uprightly for the wholeness of Indonesia. Education as a bridge of change becomes the first entrance $g$ ate into the attempt of solidifying Indonesia through education process using multicultural approach.

Banks [2] explains multiculturalism as follows: Multicultural education incorporates the idea that all students-regardless of their gender, social class, and ethnic, racial, or cultural characteristics-should have an equal opportunity to learn in school. Another important idea in multicultural education is that some students, because of these characteristics, have a better chance to learn in schools as they are currently structured than do students who belong to other groups or who have different cultural characteristics.

United States of America is a practical example (Bank, 2010) as it is a strong multiethnic state because it is glued together by the same spirit of finding universal values in living within nation and state by upholding high humanity values. Multicultural Education [2] describes the social policy based on the principles of preserving culture, sense of belonging, respecting other different cultural groups within society. Education with multicultural approach contains learning activity by emphasizing on the participation of all learners without discriminating each other by race, cultural behavior, sex, social status, identity, and etc. Learning activity at school in intra- and extracurricularactivity reflects on the democratic practice completely, curriculum represents diverse cultures, and upholds cooperative and commonality values. The students study cheerfully and are undoubted with their own identities from skin color, hair type, nose shape, eye shape, physical condition, cultural behavior, and etc compared with the emergence of prejudice and competition due to differences.

Regarding this, Bank explains, “...Practicing educators can use the dimensions as a guide to school reform when trying to implement multicultural education. The dimensions are (1) content integration, (2) the knowledge construction process, (3) prejudice reduction, (4) an equity pedagogy, and (5) an empowering school culture and social structure". There are five dimensions of multicultural education: integrated concept, knowledge construction process, prejudice reduction, pedagogy equity and culture's readiness and school organization structure playing important parts in its implementation practice. Education with multicultural approach does not lead to education institutionalization and inclusive teaching process toward infinite pluralism propaganda. However, multicultural approach attempts to empower the students to respect those with different culture, to give those different physically the opportunity of cooperating, to recognize the different cultural perspective, and to develop the students' pride for this difference and to keep us far away from conflict. Multicultural approach [12] in education has the following objectives: a)to develop ethnic and literacy and diverse culture, b) to develop tolerant and appreciating personality, c) to clarify social wisdom value and attitude in difference, d) to develop multicultural competency as the attitude in interaction, e) to develop basic skill ability in living within society, nation, and state, f) to realize education equality and superiority upholding humanity difference and values, g) to reinforce personality for a better and more well-established social reformation, h) to have strong nationality 
and statehood insights, i) to have cross-cultural nation insight as the worlds' citizens, and j) to live adjacently in peace and harmony.

\section{METHOD}

This research is conducted in a qualitative descriptive method with phenomenology approach which has been developed by Miles and Huberman [10]. This study describes a clear and comprehensive application of multicultural approach in learning process in primary school as an effort to cultivate the values of togetherness in differences for students from an early age. The research was conducted in five public elementary schools in Pasar Rebo sub-district, East Jakarta. In this research, the teachers became the key informants while supported by the presence of school principals, school committees and other elements involved.

\section{RESULT}

\section{Social Science Education in Elementary School}

Education in elementary school is an important process of a series of education level in Indonesia. Elementary school education is the basis of education sustainability and success in the future. The portion of character education, noble character, and ethics reaches $80 \%$, while that of science development $20 \%$. It is in line with Daniel Goleman's (2006) related to the effect of emotional quotient reaching $80 \%$ and intellectual quotient $20 \%$. Social Science education is closely related to the character education intended. Social Science education in many experts' perspectives pertains directly to human daily life activity including time, interaction, place, organizational system of society, and cultural system in diversity [18].The informant, GYL, (52 years old) has stated, “... that the content of the 2013 curriculum for the subject social sciences is integrated with other subjects which exhibit multicultural values. This is also seen in teacher handbooks that hace more diverse illustrations than the previous one. The problem lies in the teacher's understanding of the importance of multicultural softskill".

Social Education in elementary school gives a broad understanding on learning experience and life experience in order to be democratic citizens in a so complex cultural difference and in interdependent world (Hermana, Somantri, 2005). Richard E Gross (1978) explains that Social Science is a social educationintended to prepare the students with knowledge, skill and attitude enabling the citizens to grow personally in plural society and to have positive contribution to a nation's culture. Furthermore, Murriel Crosby explains that Social Science is a study focusing onan individual building a better life forhim/her self and his/her family, howpeople solve their social problem, how peoplelive in commonality, dependent on each other, supporting each other, changing each other and changedby each other. Generally, Social science learning in basic education level has an objective to develop the students' potency in order: a) to have awareness and caring about society, through understanding historical values and society culture, b) to find out and to understand the basic concept about social sciences that can be adapted to solving the problems 
dealt with, c) to use critical thinking process model to make decision in finding solution to a variety of issues developing within society, d) to develop self-potency in order to survive in living responsibly. Regarding this, the good social science is the one building on studying social phenomena/problems contextually [19]. This is affirmed by WWN (55 years old), “... a principal who explains that school provides the widest space for interactive learning and upholding humanity. The principals manage the classroom, play room, sports field, and all were prepared for all elements of the school regardless of gender".

Basic Competency of Social Science in elementary school is packaged in integrative manner using geographic, historical, economic, and sociological aspects as the binder elements. The basic theme of Social Science in basic education unit includes: Piety to Almighty God, state's basic philosophy, national personality, and life in state, democracy and power, right and obligation of citizens, individuals, and society, social order, and life in society, interrelation, interaction, and interdependency in life, event in time perspective, plurality in Indonesian community structure, human, and their residence environment, life need fulfillment, welfare and social justice, science and technology development, globalization, and life pattern change. Regarding this, the representation of interrelated value dimensions connected to the value content existing in Social Science learning can be seen in the figure below:

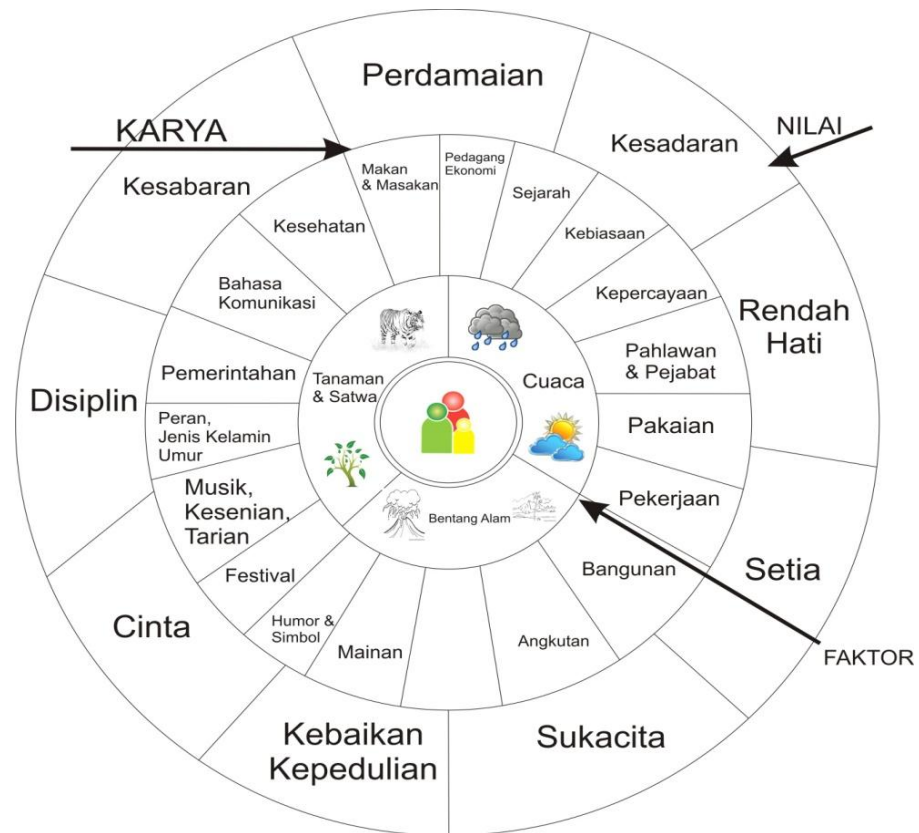

Figure 1. Figure of Interrelationship [4]

Thus, social science education in elementary school becomes a basic foundation in developing multicultural values, moreover when multicultural approach in learning becomes a part of soft skills later and soft skill characterizes the professional teacher according to the law policy. This is as revealed by informant SLL (52 years old) who explained that "the learning process in elementary school becomes the base of cultivating values which can not considered as an easy task". In this global era, the 
today's elementary school teachers must have professionalism that goes beyond their own minds. The global era allows us to meet other people with significant differences and we have to make the difference as something that strengthens us."

The 2013 curriculum as a means of transforming educationsystem in Indonesia gives a representation about Indonesian humanresource yielded. Multiculturalism as the part of global interaction becomes an important part to be developed in learnig process. What is illustrated by Pheeney [4] represents a noble character based on humanism values just like the key to multiculturalism theory. Thosevalues include peace, love, humility, loyalty, joy, goodness, care, love, discipline, patience, resoluteness toward peace in the dimension of difference because role, sex, preference, work, belief, habit, historical background, food, communication, and etc in an intact world view replete with peace. These values should underlie the development of Social Science in presenting high-quality Social Science learning.

\section{The implementation of Multicultural Approach in Social Science in Elementary School}

Generally, multicultural approach in learning is based on the attempt of: a) providing new breakthrough in learning process that can improve empathy and reduce the students' prejudice thereby creating cross-cultural human beings (citizens) who can settle the conflict without violence, b) applying potential learning approach and strategy by emphasizing on social interaction process and having strong affective content; c) helping teacher in managing learning process in order to be more efficient and effective, d) helping the students' ability of building collaboration and having high value commitment in plural community life; e) contributing to the nation in settling and managing conflict with Ethnic, Religion, and Race nuance arising in the society by improving empathy and reducing prejudice, f) implanting the awareness of important value in cultural diversity, g) reinforcing the awareness that every childhas different characteristics, having equal opportunity of acquiring education, h)improving the awareness of difference is a certainty so that it should be accepted reasonably and should not bedebated, and i) reforming education related to the opportunity gap, injustice in school opportunity, discrimination in certain group. These religious values are injected continuously as the spirit of entire learning process, whatever subject is given.this is as revealed by informant ED, (35 years) "I thought it was easy ... but in reality it is difficult. We understand the concept while others do not. However, we are not giving up because difference is real, and it should be our strength."

In relation to the implementation of multicultural approach in Social Science learning in elementary school, Pamela L Tiedt and Iris M Tiedt's (1990) analysis explains four important dimensions developed, as shown in the table below: 
TABLE 1. VALUE DIMENSIONS IN MULTICULTURAL LEARNING

\begin{tabular}{|c|c|}
\hline Dimension & Sub-dimension \\
\hline Concept Understanding & $\begin{array}{ll}\text { - } & \text { Self } \\
\text { - } & \text { Lifestyle } \\
\text { - } & \text { Culture } \\
\text { - } & \text { Individual and group transformation } \\
\text { - } & \text { Cultural contact as the means of transformation } \\
\text { - } & \text { Personal heritage } \\
\text { - } & \text { Difference in individual and group } \\
\text { - } & \text { Competency Difference } \\
\text { - } & \text { Job difference } \\
\text { - } & \text { Stereotype }\end{array}$ \\
\hline Value acquisition & $\begin{array}{l}>\text { Self-esteem } \\
>\quad \text { Self appreciation and others' appreciation } \\
>\quad \text { Respect to self and others' value and prestige } \\
>\quad \text { Respect to similarity and difference } \\
>\text { Acceptance to cultural pluralism } \\
>\text { Acceptance to different lifestyle } \\
>\quad \text { Wish to bring about equality } \\
>\text { Pish to reduce stereotype } \\
\text { Positive attitude to school and life }\end{array}$ \\
\hline Skill development & $\begin{array}{l}\text { Analyzing cultural effect } \\
\text { Analyzing equality and difference } \\
\text { Distinguishing myth from fact } \\
\text { Recognizing suspicious conduct } \\
\text { Identifying biased media } \\
\text { Interpreting personal heritage } \\
\text { Explaining self-value } \\
\text { Using skill to settle conflict }\end{array}$ \\
\hline $\begin{array}{l}\text { Personal and } \quad \text { Social } \\
\text { Behavior }\end{array}$ & $\begin{array}{l}\text { Working to reduce injustice } \\
\text { Confronting adverse conduct } \\
\text { Wollaborating with difference } \\
\text { Wtilizing community society as the resource } \\
\text { * Using school society as resource } \\
\text { Using intrapersonal skill }\end{array}$ \\
\hline
\end{tabular}

Considering the table of dimensions above, what Pamela L Tiedt and Iris M Tiedt describes represents how sub-dimension of multicultural value becomes an important part in entire learning activity implemented in realizing the human resource with positive attitude in living and in real life. Living adjacently in the conditions of peace, protection, tolerance, freeing each other from difficulty, not threatening each other, and diverse human wills becomes a part of undertaking life in diversity consciously [1]. Love to homeland is a part of faith [7] becoming the spirit of responsibility as the citizen. All of those values are effective when they are implemented through education channel within which there are learning process and social science becoming one of subjectexamples playing an important role to develop those values just like the key philosophy of Social Science learning implementation in the specified curriculum.

Improving social sensitivity in diverse life is the part of love to homeland and nation. Indonesian diversity is a well-established certainty that should be maintained, championed, and celebrated in daily life, because diversity actually is a global 
community's dream that is being tested with thousands conflicts [9]. Social Sciencelearning should convince the students and their environment about the importance of understanding this diversity as one guarantee of sustainability in living within nation and state [9]. Regarding this, Pranoto [9] reconfirms that "... intuitively, the students' experience with interaction in diversity during studying at school will result in social harmony between citizens and future generations... diverse education environment will contribute peace and harmony of living within society in the future... Class climate is needed to fertilize diversity idea symbolically and reflection rather thanrite, one-way slogan lecturing. There should be a creative approach seeing the students as the intellects that can understand the symbolicmessage in logical reasoning and explore understanding themselves".

Multicultural approach in education/learning becomes new expectation amid conflict issues and conflicts existing in our environment today. Multicultural approach should be new skill for all teachers, school leaders, school environment and society in general as a certainty in global era. The connectivity of human movement current in global era today presents a clear difference aroma and difference-based interaction between fellows. Education plays an important part in fertilizing these multicultural values. Seven important points to be developed through multicultural approach, as suggested by Julia Scherba de Valenzuela [5] are as follows: 1) multicultural education is anti racist education, 2) basis education, 3) important for all students, 4) is able to permeate/percolate, 5) is education for social justice, 6) is a process, 7) is an education with critical attitude.

\section{CONCLUSION}

The multicultural structure of Indonesian population is the main social capital to establish Republic of Indonesia Unity State. Conflict shake due to diversity problem becomes an important part in development process today. The strong global current and the technology sophistication break easily the long built multiculturalism. Education contains learning process playing a strategic role in reinforcing multicultural values as the part of learning approach. Multicultural approach in learning becomes new soft skill to teachers in Indonesia in the attempt of reinforcing diversity and difference as the basis of nationalism in global era. The multicultural approach becomes a new soft skill for all the elementary school teachers, including the school principals and other parties involved as an effort to cultivate the values of togetherness and humanity for students since early age. Theoretically the multicultural approach affirms the great effort to instill mutual value in the midst of diversity. The multicultural approaches in learning can improve empathy, ease prejudices, push honest interaction, mutual respect, help teachers to manage more efficient learning, give students the opportunity to build collaborative attitudes, avoid conlifcts related to ethnicity, religion, race, and between groups, instill the awareness of the different individual characters, et cetera. The multicultural approach becomes a new path in a more humane and equitable process in moral learning. 


\section{REFERENCES}

[1] Abdul Wahid. (2017). “Kebinekaan yang Terjagal”. Kompas. Selasa 9 Mei.

[2] Banks, James A, Cherry A Mc Gee Banks (2010). Multicultural Education Issues and Perspectives. Seventh Edition. RRD Crawfordseville.

[3] Carl A Grant and AgostinoPortera. (2011). Intercultural and Multicultural Education.

[4] Christine, Pheeney. (2014). "Cooperative Spirit “. International Conferrence on Character Education. Universitas Lambung Mangkurat Kalimantan Selatan.

[5] Dadang Supardan. (2015). Manusia, Kekerasan, Multikultural dan Transformasi Pendidikan. Bandung:Rizqi.

[6] Fattah Hanurawan and Peter Waterworth. (1997). "Multicultural Perspective In Indonesia Social Studies Education Curriculum". The Journal Of Education Vol 4 Special Edition.

[7] Fathorrahman Ghufron. (2017). "Kembali ke Pancasila". Kompas. Kamis, 20 Juli

[8] Gloria Ladson \& Billing William F Tate. (2006). Research In The Public Interest Sosial Justice Action and Policy. Teachers College Press. Columbia University

[9] Iwan Pranoto. (2017). "Paradoks Tragis Kebinekaan di Pendidikan. Kompas. Sabtu 15 Juli.

[10] Miles, Mattew dan A Huberman. (2007). Analisis Data Kualitatif. Alih Bahasa : Tjejep Rohendi. Jakarta : Universitas Indonesia.

[11] Pamela L Tiedt and Iris M Tiedt. (1990). Multicultural Teaching : A Handbook of Activities, Information and Resources. Massachusetts: Allyn and Bacon.

[12] Sleeter, C.E and Grant CA. (1993). Making Choices For Multicultural Education: Five Approaches To Race, Class and Gender. New York : Merrill

[13] Subhan SD. (2017). “Kekuatan Zaman”.KolomPolitikKompas. Sabtu 22 Juli

[14] Syafiq, Hasyim. (2017). "Involusi Makna Toleransi”. Kompas.Senin 15 Mei

[15] Supandi. (2006). "Pendidikan Sejarah Lokal Dalam Konteks Multikultural”. Jurnal Cakrawala Pendidikan. UniversitasNegeri Yogyakarta Februari XXV 101

[16] Suswandari. (2010). "Paradigma Pendidikan Sejarah dalam Menghadapi Tantangan Masa Depan”. Cakrawala Pendidikan : Jurna; Ilmiah Pendidikan. UNY. ISSN 0216 1370, ISSN 24438620.

[17] Suswandari. (2014). "Integrasi Nilai-Nilai Kesetaraan Gender Dalam Pembelajaran Ilmu Pengetahuan Sosial Menuju Pembentukan Karakter Siswa Sekolah Dasar". Pidato Pengukuhan Guru Besar. Universitas Muhammadiyah Prof. DR. HAMKA.

[18] Suswandari. (2016). "Pemahaman Sejarah, Budaya dan Kearifan Lokal Etnik Betawi Pada Guru Sekolah Dasar di Wilayah DKI Jakarta". Prosiding Kolokium Doktor dan Seminar Hasil Penelitian . Lembaga Penelitian dan Pengembangan Universitas Muhammadiyah Prof. DR. HAMKA.

[19] Suswandari. (2017). 'Pendekatan Etnopedago di dalam Pembelajaran IPS di Sekolah Dasar". Seminar Internasional UHAMKA.

[20] Suswandari, (2017). "Local History of Jakarta and Multicultural Attitude (Historical Local study of Betawi Ethnic)". JETL : Journal of Education Teaching and Learning . P ISSN 2477.5924, E ISSN 2477-8478. Institute For Managing and Publishing Scientific Journal STKIP Singkawang

[21] Tilaar, HAR. (2004). Multikulturalisme Tantangan Global Masa Depan Dalam Transformasi Pendidikan. Jakarta: Gramedia. 